Article

\title{
Formation of $\mathrm{Nb}(\mathrm{C}, \mathrm{N})$ Carbonitride in Cast Austenitic Heat-Resistant Steel during Directional Solidification under Different Withdraw Rates
}

\author{
Yinhui Zhang ${ }^{1,2, *}$ and Jian Yang ${ }^{1, *}$ \\ 1 State Key Laboratory of Advanced Special Steel, School of Materials Science and Engineering, \\ Shanghai University, Shanghai 200444, China \\ 2 State Key Laboratory for Advanced Metals and Materials, University of Science and Technology Beijing, \\ Beijing 100083, China \\ * $\quad$ Correspondence: yinhuizhang@shu.edu.cn (Y.Z.); yang_jian@t.shu.edu.cn (J.Y.); Tel.: +86-021-6613-6580 (J.Y.)
}

Received: 26 October 2018; Accepted: 26 November 2018; Published: 28 November 2018

\begin{abstract}
It is recognized recently that primary "Chinese-script" $\mathrm{Nb}(\mathrm{C}, \mathrm{N})$ carbonitride is critical to the development of cast austenitic heat-resistant steels for ultra-high temperature applications. In this paper, the precipitation behavior of $\mathrm{Nb}(\mathrm{C}, \mathrm{N})$ carbonitride in a novel creep and fatigue resistant steel was investigated by the use of the liquid metal cooling directional solidification (LMC-DS) method under different withdraw rates. Thermodynamic calculations were also performed to aid in the understanding of the solidification behavior. Microstructural characterization and thermodynamic calculation agreed that the alloy solidified in the path of primary austenite, eutectic $\mathrm{Nb}(\mathrm{C}, \mathrm{N})$ carbonitride, and secondary ferrite, regardless of the withdraw rate. However, the primary and secondary dendrite arm spacing decreased significantly with an increase in the withdraw rate, and a quantitative relationship was established. Furthermore, the eutectic reaction range increased at a higher withdraw rate, due to the rapid increase of the solid phase fraction and the accumulation of solutes in the interdendritic liquid phase. This gave rise to a decline in the interlamellar spacing of primary $\mathrm{Nb}(\mathrm{C}, \mathrm{N})$ carbonitride sheets and rods for the higher withdraw rate. Therefore, a fine "Chinese-script" $\mathrm{Nb}(\mathrm{C}, \mathrm{N})$ carbonitride in this type of alloys can be achieved through increasing the withdraw rate or the cooling rate during casting.
\end{abstract}

Keywords: austenitic steel; carbonitride; directional solidification; growth rate; morphology

\section{Introduction}

In recent years, more strict environmental and fuel consumption regulations have been placed worldwide, aiming at reducing exhaust gas emissions and preventing global warming [1]. For the automotive industry, gas emissions can be reduced by increasing the operating temperature and pressure of automotive engines, with a further benefit of increasing the engine power [2]. The gas temperature of gasoline engines now reaches as high as $1050^{\circ} \mathrm{C}$, approximately $200^{\circ} \mathrm{C}$ higher than the conventional gas temperatures [3]. This results in many failure events of exhaust manifolds and turbine housings in automotive exhaust systems, made by incumbent materials (SiMo cast iron and Ni-resist D5S, etc.) $[4,5]$. Therefore, automotive industries are in need of developing novel and cost-effective alloys for such ultra-high temperature applications.

Candidate structural materials of interest comprise ferritic and austenitic heat-resistant steels with superior mechanical properties and oxidation resistance at high temperatures, as well as Ni-based superalloys [1,6]. Because of the complex shape of the exhaust components, the cast grade of these materials are specially demanded [5]. A new family of $\mathrm{Nb}$-bearing cast austenitic heat-resistant 
steels is currently under development by the authors [7-11]. These alloys exhibit much better creep properties than that of commercial alloy 1.4826 at $1000{ }^{\circ} \mathrm{C}$, owing to the precipitation of primary and secondary $\mathrm{Nb}(\mathrm{C}, \mathrm{N})$ carbonitride [12]. Particularly, the primary "Chinese-script" $\mathrm{Nb}(\mathrm{C}, \mathrm{N})$ carbonitride can prevent grain boundary sliding and strengthen the interdendritic regions, thus improving the creep property more effectively than the blocky carbonitride [13]. Furthermore, this "Chinese-script" $\mathrm{Nb}(\mathrm{C}, \mathrm{N})$ carbonitride, rather than the blocky one, can improve the thermo-mechanical fatigue properties, since it delays the nucleation and propagation of fatigue cracks [11,14]. Therefore, a key demand for creepand fatigue-resistant cast austenitic heat-resistant steels is to form fine "Chinese-script" $\mathrm{Nb}(\mathrm{C}, \mathrm{N})$ carbonitride during casting.

The formation of primary $\mathrm{Nb}(\mathrm{C}, \mathrm{N})$ carbonitride associates profoundly with the composition and casting of these austenitic alloys. Extensive studies on the compositional effects in Ni-based superalloys and austenitic steels have established that $\mathrm{C}, \mathrm{Nb}$ and $\mathrm{Y} / \mathrm{Ce}$ additions improve the formation of "Chinese-script" MC-type carbide, whilst Ti and Hf additions accelerate faceted and blocky MC-type carbide precipitation [15-22]. Our previous studies have recognized that $\mathrm{N}$ additions will transform this carbonitride morphology from "Chinese-script" to blocky features as well [23]. However, $\mathrm{N}$ is a powerful austenite stabilizer, which can substitute $\mathrm{Ni}$, a common but relatively expensive austenite stabilizer, thereby reducing the cost [24]. It is therefore required that the morphology of $\mathrm{Nb}(\mathrm{C}, \mathrm{N})$ carbonitride is controlled by optimizing the casting process.

Several studies on Ni-based alloys have highlighted that MC-type carbide is irregularly shaped for high cooling rates, and spheroidized for low cooling rates $[16,25,26]$. For austenitic steels, Buchanan et al. has recently recognized that the morphological difference of MC-type carbide is determined by the nucleation sites: on the existing austenite dendrite, or in the liquid phase ahead of the liquid-solid (L/S) interface, or on Ti-rich spheres in the liquid phase [27,28]. However, the formation mechanism of $\mathrm{Nb}(\mathrm{C}, \mathrm{N})$ carbonitride has not been investigated thoroughly, particularly in cast austenitic heat-resistant steels with relatively high $\mathrm{Nb}$ contents.

Therefore, the aim of the current research is to investigate the precipitation behavior of $\mathrm{Nb}(\mathrm{C}, \mathrm{N})$ carbonitride under different solidification conditions. For this purpose, a novel cast austenitic heat-resistant steel with a good combination of creep, fatigue, and oxidation resistance was deliberately selected from our alloy system. The liquid metal cooling directional solidification (LMC-DS) method was applied to offer real microstructural developments during solidification. In the presence of the LMC-DS system, the temperature gradient was kept constant, whilst the withdraw rate varied from 20 to $50 \mu \mathrm{m} / \mathrm{s}$. Computational thermodynamic calculations were also performed to aid in the interpretation of the solidification behaviors. Based on these experimental and simulation methods, the solidification path of this alloy was identified, and a relationship between the microstructure and withdraw rate was established. The generated data and understanding will help to optimize the casting process of this type of alloy, and to improve their ultra-high temperature mechanical properties.

\section{Materials and Methods}

A novel cast austenitic heat-resistant steel named alloy $3 \mathrm{C} 2 \mathrm{~N}$ was studied in the current research. This alloy was melted in a vacuum induction furnace, and cast into a cylindrical ingot with a diameter of $80 \mathrm{~mm}$, weighing about $20 \mathrm{~kg}$. The chemical composition was quantitatively analyzed by inductively coupled plasma atomic emission spectrometry (ICP-AES) for $\mathrm{Ni}, \mathrm{Mn}, \mathrm{Nb}$, and $\mathrm{P}$, ammonium persulfate oxidation titration for $\mathrm{Cr}$, infrared absorption for $\mathrm{C}$ and $\mathrm{S}$, conductivity for $\mathrm{N}$, and gravimetric method for $\mathrm{Si}$, and it is summarized in Table 1. The ingot was machined into directional solidification (DS) bars with lengths and diameters of 100 and $6 \mathrm{~mm}$, respectively. These DS bars were then mechanically ground by $\mathrm{SiC}$ emery papers up to 600 grit prior to the DS experiments.

LMC-DS technology, an effective method for solidification investigation [10,23], was applied in the current research. This technology is based on the Bridgman-type DS concept that the DS bar is withdrawn from the hot zone to the cold zone at a controlled speed, so that the L/S interface resides within the transition region (mushy zone) [29]. Different from the traditional Bridgman type 
DS technology that relies on relatively inefficient radiation cooling, the LMC-DS technology utilizes a low-melting-point, liquid-metal coolant in the cold zone to extract heat more efficiently, and therefore, the solidification microstructure can be well preserved. Figure 1 shows the schematic illustration of the LMC-DS processing [10]. The DS bar was melted in the graphite induction furnace, with a maximum heating temperature of about $2000{ }^{\circ} \mathrm{C}$, and a vacuum degree of $10^{-4} \mathrm{~Pa}$. It then moved vertically under withdraw rates of 20 and $50 \mu \mathrm{m} / \mathrm{s}$, and solidified under a temperature gradient of $10^{\circ} \mathrm{C} / \mathrm{mm}$, controlled by a W-Re5/26 thermocouple [30]. After directional solidification to a constant length of $50 \mathrm{~mm}$, the DS bar was quenched immediately by a rapid displacement of the alumina crucible into the liquid metal bath (Ga-In-Sn).

Table 1. Measured chemical composition of as-cast alloy 3C2N (mass \%).

\begin{tabular}{ccccccccccc}
\hline Alloy & Fe & Cr & Ni & Si & Mn & Nb & S & P & C & N \\
\hline 3C2N & Bal. & 19.68 & 10.12 & 0.80 & 0.93 & 2.09 & 0.008 & 0.013 & 0.29 & 0.15 \\
\hline
\end{tabular}

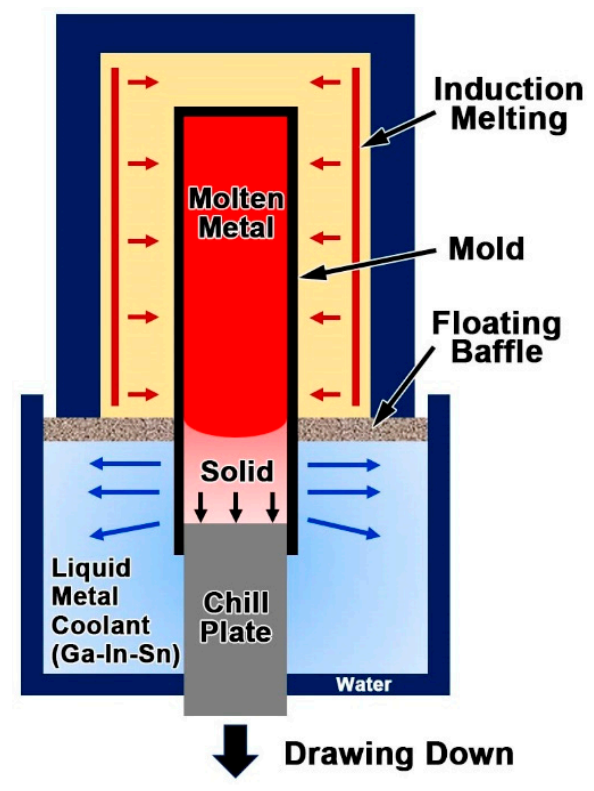

Figure 1. Schematic illustration of the LMC-DS processing [10].

Subsequently, the DS bars were sectioned longitudinally to investigate the quenched interfacial morphology and microstructural development during the LMC-DS process. The specimens for macro-grain structure observation were mechanically ground by $\mathrm{SiC}$ emery papers up to 1000 grit, prior to etching in a solute of $20 \% \mathrm{H}_{2} \mathrm{O}_{2}+40 \% \mathrm{HCl}+40 \% \mathrm{H}_{2} \mathrm{O}$. The specimens for microstructure analyses were mechanically ground as well, but up to 3000 grit, and then polished by $0.1 \mu \mathrm{m}$ diamond powder without etching. The macro-grain structure was examined by the use of an office scanner, whilst the microstructure was characterized utilizing an Axio Imager A2m optical microscope (OM, ZEISS Ltd., Oberkochen, Germany) and a SUPRA 55 field emission-scanning electron microscope (FE-SEM, ZEISS Ltd., Oberkochen, Germany), operated in backscattered electron (BSE) imaging mode. The composition of the liquid phase in the mushy zone was determined by a JXA-8530F field emission electron probe microanalyzer (FE-EPMA, JEOL Ltd., Tokyo, Japan), equipped with five wavelength-dispersive spectrometers (WDS).

Thermodynamic calculation was also carried out to aid in the interpretation of the solidification behavior of alloy 3C2N, by the use of the JMatPro software (version 5.0, Sente Software Ltd., Guildford, UK) with a stainless-steel database. The phase diagram was calculated under the equilibrium condition, whilst the solidification sequence of different phases was calculated under the Scheil-Gulliver condition. The measured chemical composition listed in Table 1 was used for these calculations. 


\section{Results}

\subsection{Thermodynamic Calculations}

In order to predict the microstructure of as-cast alloy $3 \mathrm{C} 2 \mathrm{~N}$, its phase diagram was calculated by using JMatPro software under the equilibrium condition, and plotted in Figure 2. It predicted that the microstructure of as-cast alloy $3 \mathrm{C} 2 \mathrm{~N}$ consisted of $\mathrm{Nb}(\mathrm{C}, \mathrm{N})$ carbonitride and a small amount of $(\mathrm{Cr}, \mathrm{Fe})_{23} \mathrm{C}_{6}$ carbide on the austenitic matrix at a service temperature of $1000{ }^{\circ} \mathrm{C}$. This $\mathrm{Nb}(\mathrm{C}, \mathrm{N})$ carbonitride would transform into the $\mathrm{Z}$-phase $(\mathrm{CrNbN})$ as the temperature decreased below $800{ }^{\circ} \mathrm{C}$, along with the formation of $(\mathrm{Cr}, \mathrm{Fe})_{23} \mathrm{C}_{6}$ carbide, $\sigma$-phase, and ferrite. However, these equilibrium phases at lower temperatures might not form in the as-cast microstructure, due to rapid casting processing. Therefore, the phases that formed during the liquid-solid reaction and resided in as-cast microstructure were simulated by the JMatPro software under the Scheil-Gulliver condition, and plotted in Figure 3. The phases were predicted to solidify in the sequence as:

$$
\mathrm{L} \rightarrow \mathrm{L}+\gamma \rightarrow \mathrm{L}+\gamma+\mathrm{Nb}(\mathrm{C}, \mathrm{N}) \rightarrow \mathrm{L}+\gamma+\mathrm{Nb}(\mathrm{C}, \mathrm{N})+\delta \rightarrow \gamma+\mathrm{Nb}(\mathrm{C}, \mathrm{N})+\delta
$$

A relatively high fraction of $\delta$-ferrite was retained at the end of solidification, different from that predicted in the equilibrium phase diagram. Besides, no $(\mathrm{Cr}, \mathrm{Fe}){ }_{23} \mathrm{C}_{6}$ carbide was predicted in this liquid-solid reaction stage. It is thus presumed that the microstructure of the as-cast alloy $3 \mathrm{C} 2 \mathrm{~N}$ was composed of $\mathrm{Nb}(\mathrm{C}, \mathrm{N})$ carbonitride and residual $\delta$-ferrite on the austenitic matrix.

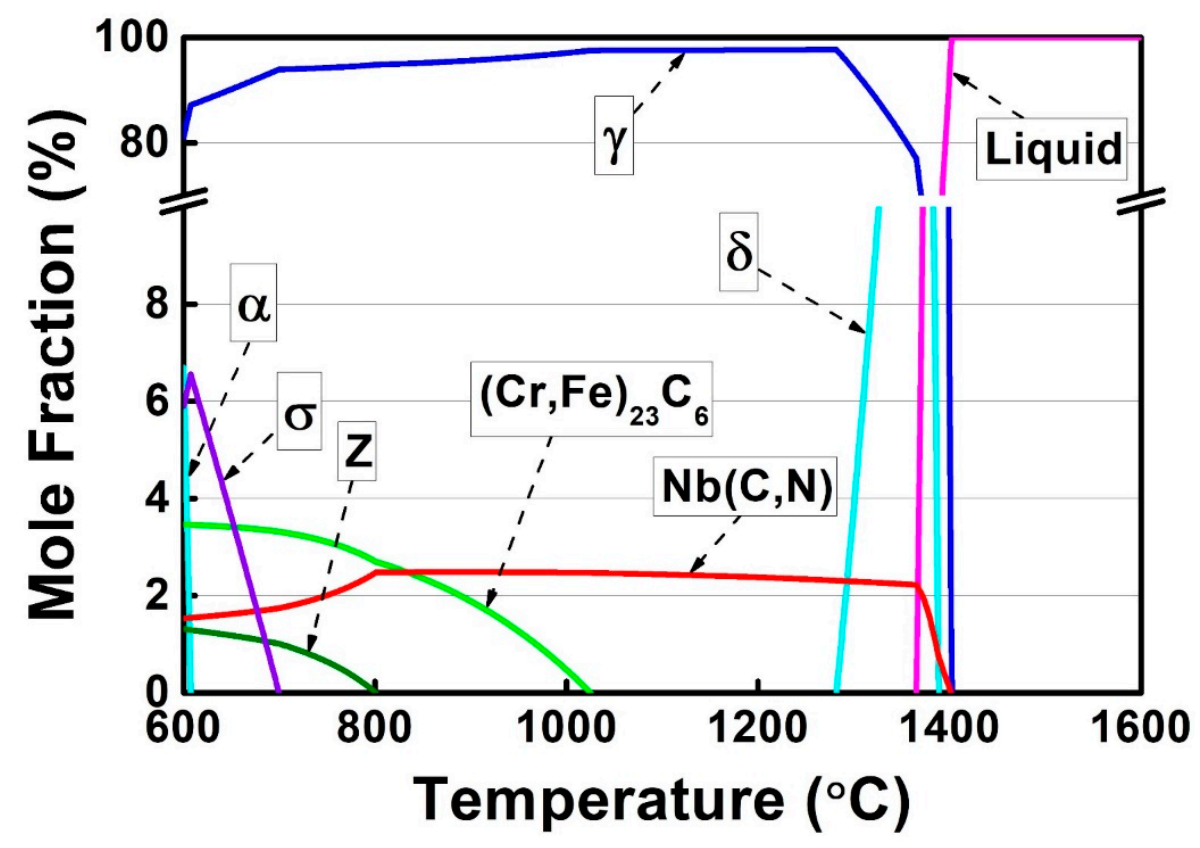

Figure 2. Phase diagram of alloy 3C2N calculated by JMatPro software under the equilibrium condition. 


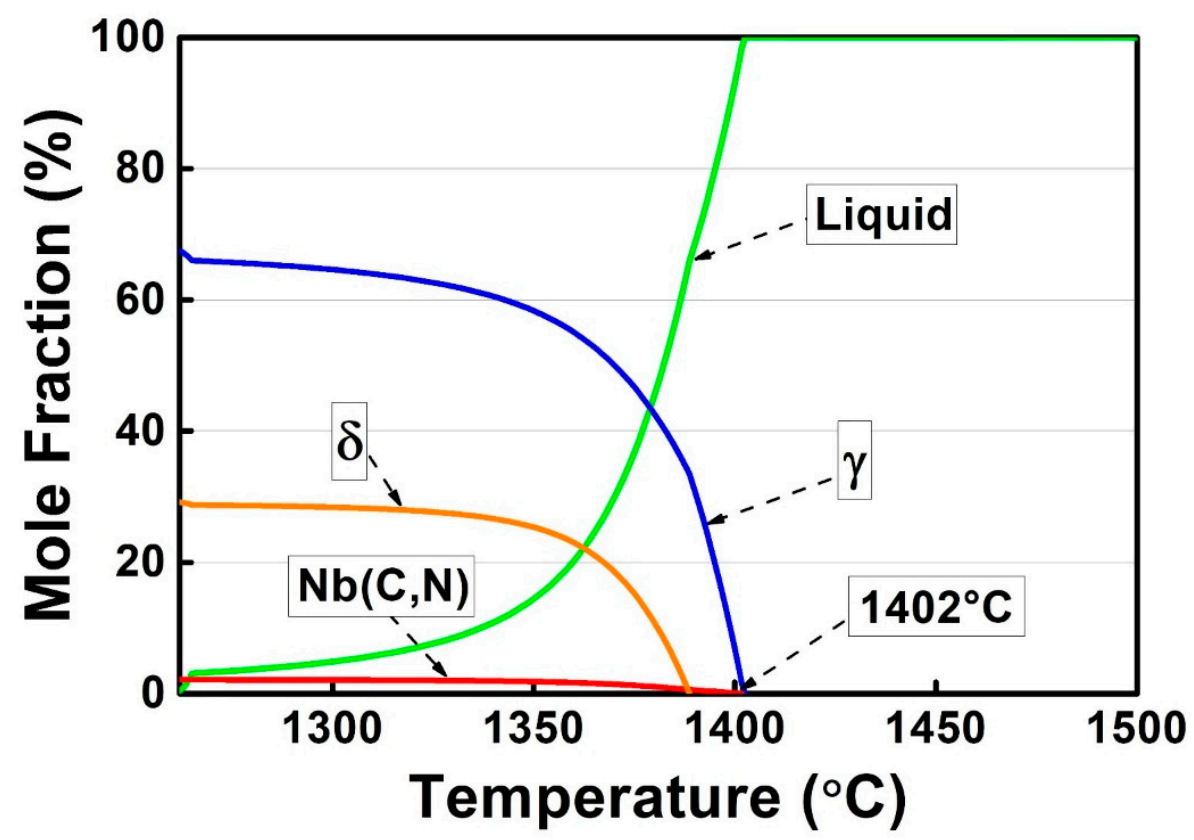

Figure 3. Mole fractions of different phases that formed during the liquid-solid solidification of alloy $3 \mathrm{C} 2 \mathrm{~N}$, calculated by JMatPro software under the Scheil-Gulliver condition.

\subsection{Microstructure of the as-Cast Ingot}

The microstructure of the as-cast alloy $3 \mathrm{C} 2 \mathrm{~N}$ was characterized before LMC-DS processing. Figure $4 \mathrm{a}, \mathrm{b}$ are optical and scanning electron microscope-backscattered electron (SEM-BSE) images showing the typical microstructure of the as-cast ingot at different magnifications. Figure 4a shows that the microstructure was composed of austenitic dendrites and duplex interdendrites, along with some black-contrast vermicular structures decorating the grain boundaries. Figure $4 \mathrm{~b}$ shows that these duplex interdendrites consisted of lamellar precipitates with white contrast and interlamellar austenites, exhibiting the "Chinese-script" morphology. The vermicular structure comprised two type of precipitates: the cellular precipitate with black contrast, and the blocky precipitate with gray contrast (Figure 4 b). Scanning electron microscope-energy dispersive spectrometer (SEM-EDS) analyses indicated that the lamellar precipitate was enriched in $\mathrm{Nb}, \mathrm{C}$, and $\mathrm{N}$, whilst the vermicular structure was enriched in $\mathrm{Cr}$ and $\mathrm{Fe}$. These precipitates were further identified by transmission electron microscope (TEM) and corresponding selected area diffraction pattern (SADP) analyses, confirming the white-contrast precipitate as $\mathrm{Nb}(\mathrm{C}, \mathrm{N})$ carbonitride, the black-contrast one as $(\mathrm{Cr}, \mathrm{Fe}){ }_{23} \mathrm{C}_{6}$ carbide, and the gray-contrast one as residual $\delta$-ferrite.

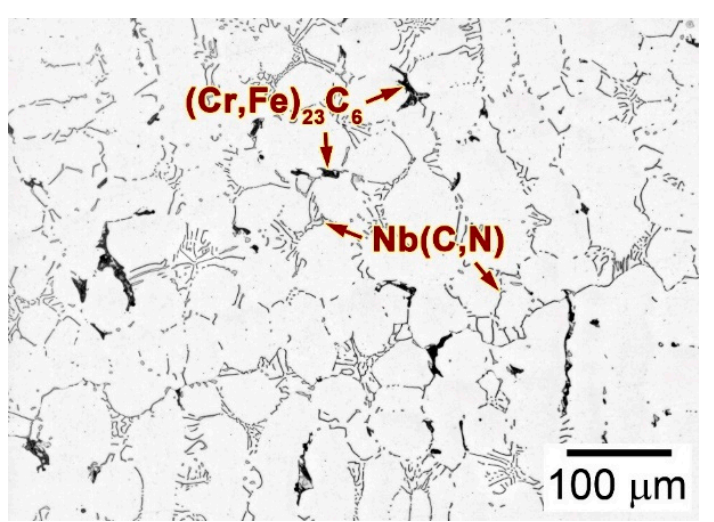

(a)

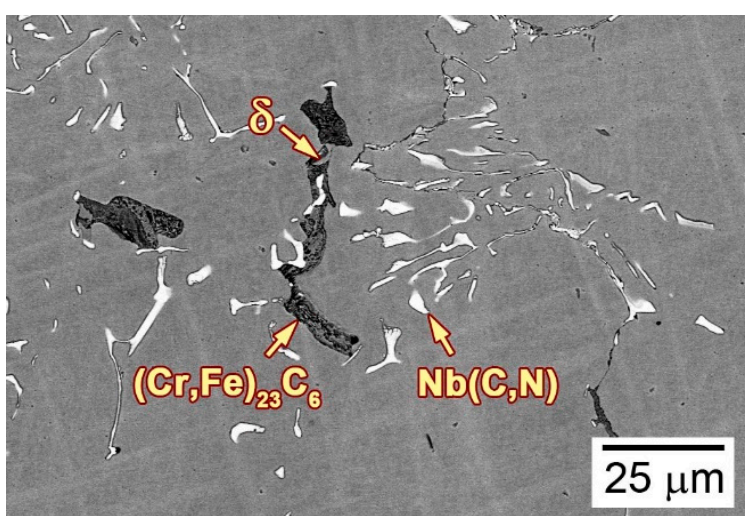

(b)

Figure 4. (a) Optical and (b) scanning electron microscope-backscattered electron (SEM-BSE) images showing the microstructure of as-cast alloy $3 \mathrm{C} 2 \mathrm{~N}$. 


\subsection{Microstructural Developments during Directional Solidification}

\subsubsection{Macro-Grain Structures}

The LMC-DS processing was adopted in the current research to investigate the solidification behavior of as-cast alloy $3 \mathrm{C} 2 \mathrm{~N}$ under different withdraw rates. The macro-grain structures after the LMC-DS processing are shown in Figure 5a,b from the longitudinal view. The DS bar exhibited several distinct grain zones at the withdraw rate of $20 \mu \mathrm{m} / \mathrm{s}$ (Figure 5a), corresponding to different solidification stages during the LMC-DS process. These grain zones were denoted as the as-cast zone, the competitive zone, the steady-state zone, the mushy zone, and the quenched liquid zone, in order of solidification sequence. The as-cast zone referred to the region that was not melted during the LMC-DS process, and thus, the coarse equiaxed grains were retained. The competitive zone consisted of fine columnar grains with different growth directions, whilst the steady-state zone revealed much coarser columnar grains with the growth direction being parallel to the temperature gradient direction. The mushy zone indicated the region where liquid and solid phases co-existed during the LMC-DS process, and the detailed microstructural characterization is presented in Section 3.3.2. The average columnar grain length and width within the mushy zone and the steady-state zone were measured to be $22.3 \pm 6.1$ and $2.4 \pm 0.7 \mathrm{~mm}$ at a withdraw rate of $20 \mu \mathrm{m} / \mathrm{s}$. After directional solidification to the constant length of $50 \mathrm{~mm}$, the DS bar was quenched in the liquid metal bath, thus forming extremely fine equiaxed grains in the quenched liquid zone.

At a withdraw rate of $50 \mu \mathrm{m} / \mathrm{s}$, the DS bar solidified in order of the similar five distinct stages (Figure 5b), but showing different solidification widths and columnar grain sizes from that at $20 \mu \mathrm{m} / \mathrm{s}$. When increasing the withdraw rate, the competitive zone expanded, while the steady-state zone contracted during the LMC-DS process, except for the mushy zone, which remained constant. Moreover, the number of columnar grains increased within the mushy zone and the steady-state zone, with the average columnar grain length and width measured to be $21.5 \pm 8.2$ and $1.7 \pm 0.6 \mathrm{~mm}$, respectively. Analyzing such change requires detailed microstructural characterization of each solidification zone in these DS bars under the two withdraw rates.

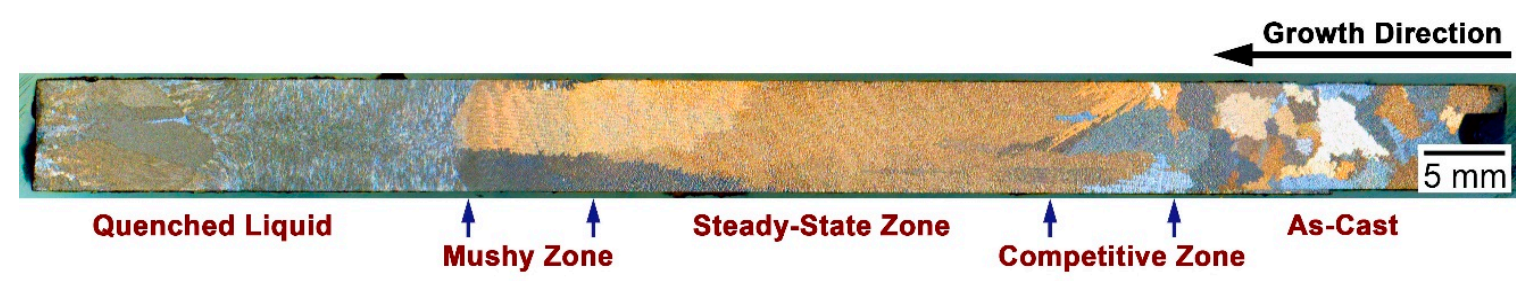

(a)

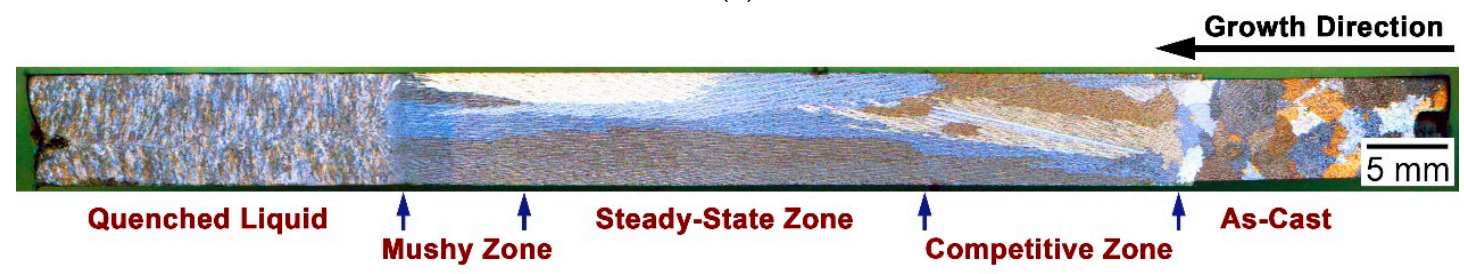

(b)

Figure 5. Optical images of longitudinal macro-grain structures in as-cast alloy 3C2N after the LMC-DS processing under different withdraw rates: (a) 20 and (b) $50 \mu \mathrm{m} / \mathrm{s}$.

\subsubsection{Microstructures}

The mushy zones of the DS bars were characterized to elucidate the effect of the withdraw rate on the solidification behavior of as-cast alloy 3C2N during the LMC-DS process. Figure 6 shows the longitudinal microstructures of the mushy zones in as-cast alloy 3C2N under the withdraw rates of 20 and $50 \mu \mathrm{m} / \mathrm{s}$. The solidification locations with solid-phase fractions of 0 and $100 \%$, known as the $\mathrm{L} / \mathrm{S}$ interface and the quenching interface, corresponded to the initiation and termination of the mushy 
zones in the current research. Their temperatures (i.e., the liquidus and solidus temperatures) were measured to be 1428 and $1356^{\circ} \mathrm{C}$ by DSC analyses, respectively. The temperature gradients of the two DS bars were then calculated to be 9.2 and $9.6^{\circ} \mathrm{C} / \mathrm{mm}$ by measuring the temperature range and width of the mushy zones, approximating to the constant $\left(10^{\circ} \mathrm{C} / \mathrm{mm}\right)$ of the DS system.

The mushy zone withdrawn at $20 \mu \mathrm{m} / \mathrm{s}$ exhibited that the primary austenitic dendrites aligned themselves well in the direction of the temperature gradient, and grew towards the molten metal (Figure 6a). The primary dendrite arm spacing (PDAS) was determined to be $298.2 \pm 44.3 \mu \mathrm{m}$ at the lower positions of the mushy zone. The secondary dendrite arms were orthogonal to the primary arms, with the spacing (SDAS) being determined to be $88.8 \pm 9.5 \mu \mathrm{m}$. The residual liquid phase in the interdendritic regions was gradually consumed to form $\gamma$-austenite, $\mathrm{Nb}(\mathrm{C}, \mathrm{N})$ carbonitride, and $\delta$-ferrite. Particularly, the $\mathrm{Nb}(\mathrm{C}, \mathrm{N})$ carbonitride was observed to nucleate and grow through the eutectic reaction:

$$
\mathrm{L} \rightarrow \mathrm{Nb}(\mathrm{C}, \mathrm{N})+\gamma_{(2)}
$$

Therefore, the mushy zone can be divided into five different liquid-solid reaction stages, comprising the full liquid stage (stage I), the primary $\gamma$-austenite solidification stage (stage II), the eutectic reaction stage (stage III), the interdendritic $\delta$-ferrite solidification stage (stage IV), and the complete solid stage (stage V). The initiation location of each reaction stage was marked in Figure 6a as well.

With an increase in the withdraw rate to $50 \mu \mathrm{m} / \mathrm{s}$, the primary austenitic dendrites still paralleled the direction of the temperature gradient in the mushy zone, and grew in the order of the same five reaction stages (Figure 6b). The PDAS was determined to be $152.4 \pm 14.0 \mu \mathrm{m}$, approximately half of that at $20 \mu \mathrm{m} / \mathrm{s}$. The secondary dendrites were significantly finer as well, with the SDAS determined to be $42.3 \pm 3.1 \mu \mathrm{m}$. Moreover, the $\mathrm{Nb}(\mathrm{C}, \mathrm{N})$ carbonitride precipitated at higher positions of the mushy zone, thus expanding the eutectic reaction stage by $0.9 \mathrm{~mm}$ (about $9^{\circ} \mathrm{C}$ ).

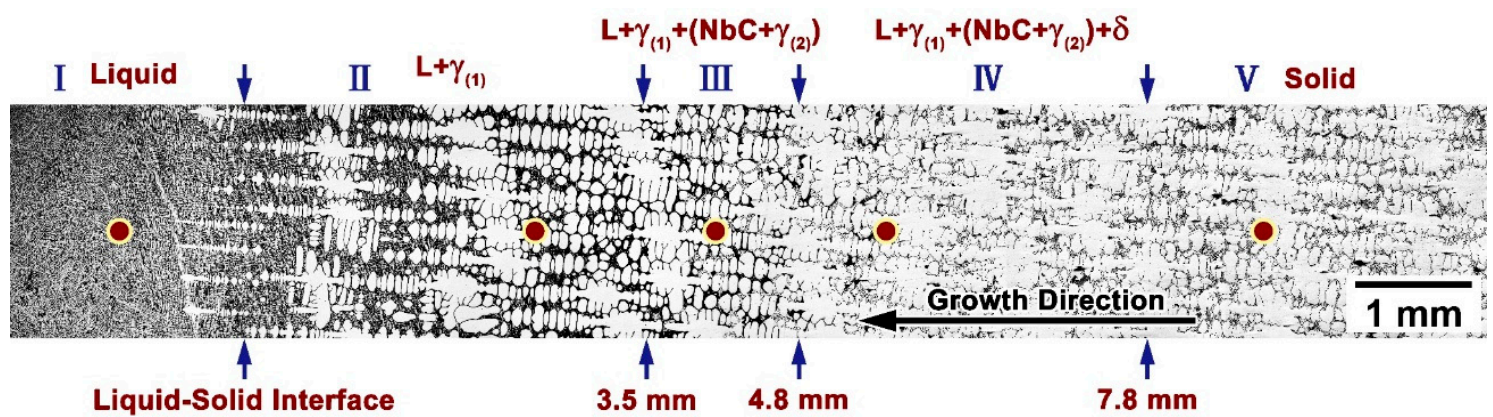

(a)

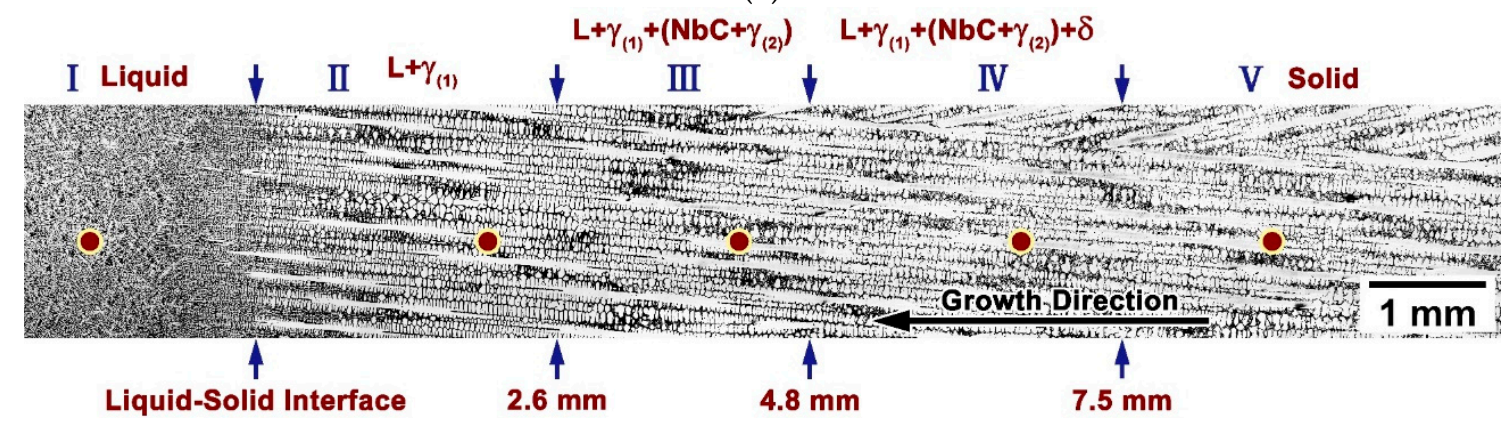

(b)

Figure 6. Optical images of longitudinal microstructures of the mushy zones in as-cast alloy $3 \mathrm{C} 2 \mathrm{~N}$ after the LMC-DS processing under different withdraw rates: (a) 20 and (b) $50 \mu \mathrm{m} / \mathrm{s}$.

Volume fractions of solid phase in the two mushy zones are plotted in Figure 7 as a function of distance from the L/S interface. When the temperature decreased below the liquidus temperature, solidification started with a sharp increase in the volume fraction of solid phase. Two obvious peaks 
were observed on the volume fraction cure withdrawn at $20 \mu \mathrm{m} / \mathrm{s}$, corresponding well to the coarse, nodular dendrites in stage II, as shown in Figure 6a. The volume fraction increased continuously and slowly in stage III and IV. Comparing the two curves, it was agreed that the eutectic reaction occurred only when the volume fraction exceeded $65 \%$.

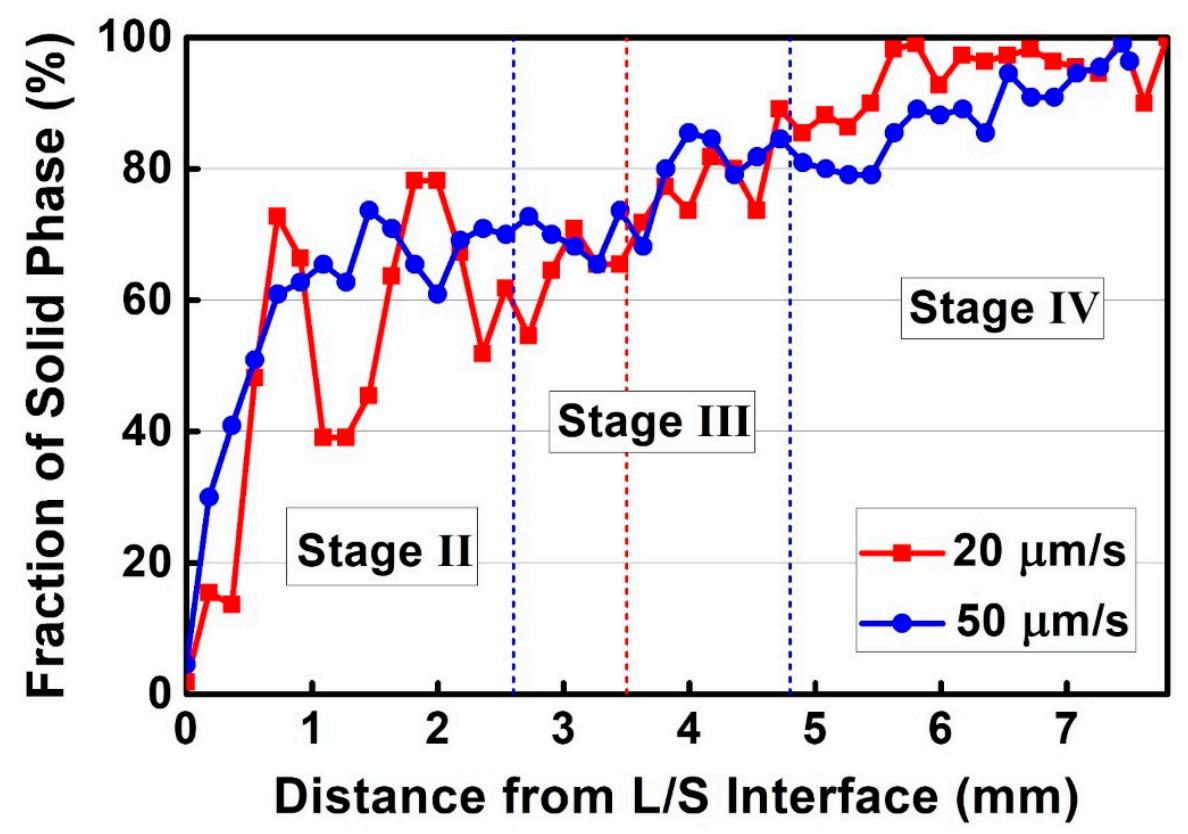

Figure 7. Volume fractions of solid phase in the mushy zones of as-cast alloy $3 \mathrm{C} 2 \mathrm{~N}$ during the LMC-DS process under withdraw rates of 20 and $50 \mu \mathrm{m} / \mathrm{s}$.

Typical locations at all solidification stages in Figure 6a,b were analyzed in detail to examine the solidification path of as-cast alloy 3C2N. Figure 8 shows the typical microstructure of each solidification stage marked by red circles in Figure $6 a$ at the withdraw rate of $20 \mu \mathrm{m} / \mathrm{s}$. Stage I exhibited the extremely fine dendritic structure (Figure 8a1), in which the interdendritic constituent consisted of the white-contrast $\mathrm{Nb}(\mathrm{C}, \mathrm{N})$ carbonitride (marked by " 1 ") and the black-contrast $\delta$-ferrite (marked by "2") (Figure 8a2). These fine precipitates, as well as the small dendritic structure were presumed to form during the final quenching process, whose withdraw rate was overwhelmingly higher than the steady withdraw rate $(20$ and $50 \mu \mathrm{m} / \mathrm{s})$. At stage II, the $\gamma$-austenite solidified first and formed a relatively coarse dendritic structure (Figure $8 \mathrm{~b} 1$ ). The liquid phase resided in the interdendritic regions, where it extended in all directions, thereby preventing the bridge-connection of dendrites. This residual liquid phase had a similar fine structure (Figure 8b2) to that in stage I, indicating that it was well preserved during the final quenching process. As temperature decreased to stage III, $\mathrm{Nb}(\mathrm{C}, \mathrm{N})$ carbonitride started to nucleate and grow at the expense of the residual liquid phase (Figure 8c1). This was well-recognized as the eutectic reaction (Equation (2)), by which the $\mathrm{Nb}(\mathrm{C}, \mathrm{N})$ carbonitride formed the typical "Chinese-script" morphology (Figure 8c2). After the eutectic reaction, $\delta$-ferrite solidified by consuming the rest of the liquid phase, and exhibited a vermicular morphology in the interdendritic regions (Figure $8 \mathrm{~d} 1, \mathrm{~d} 2$ ). Stage V showed the complete solid structure consisting of the "Chinese-script" $\mathrm{Nb}(\mathrm{C}, \mathrm{N})$ and the vermicular $\delta$-ferrite (Figure 8e1). By comparison with the as-cast microstructure before the LMC-DS processing (Figure $4 \mathrm{~b}$ ), the size and quantity of the residual $\delta$-ferrite increased obviously, without any $(\mathrm{Cr}, \mathrm{Fe})_{23} \mathrm{C}_{6}$ carbide precipitation (Figure 8e2). 


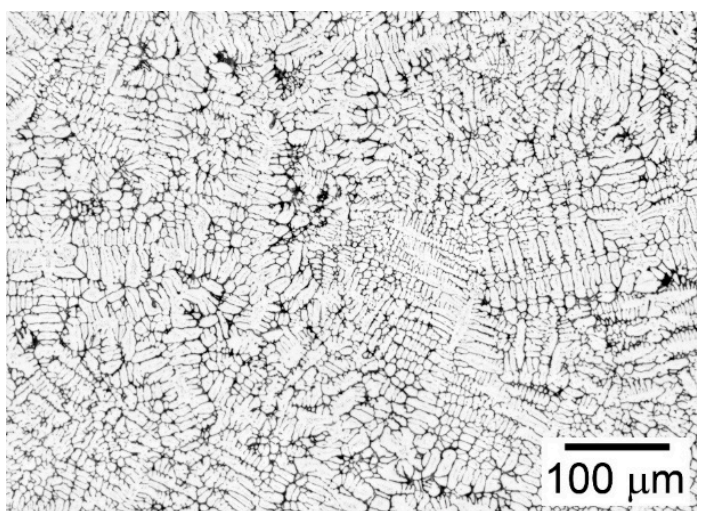

(a1)

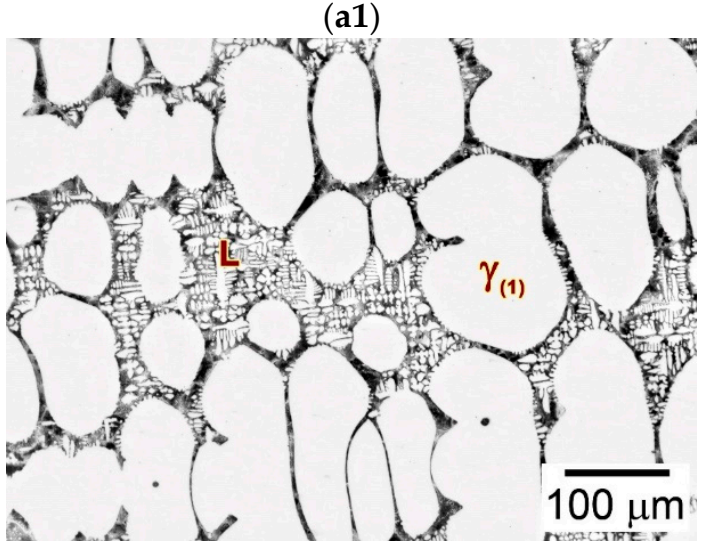

(b1)

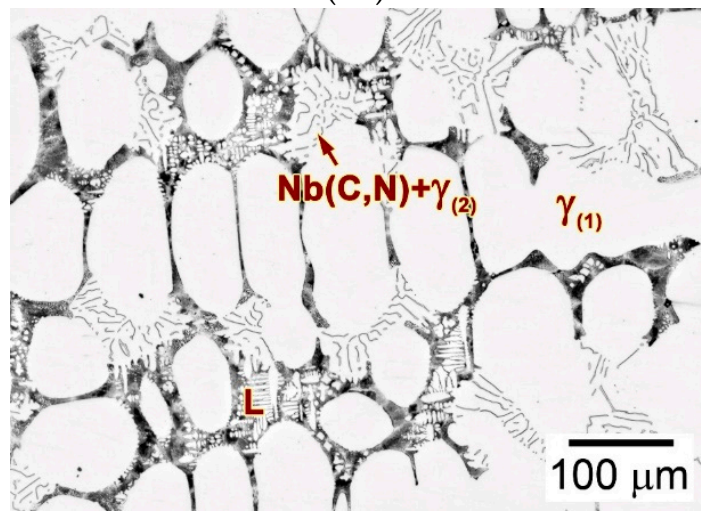

(c1)

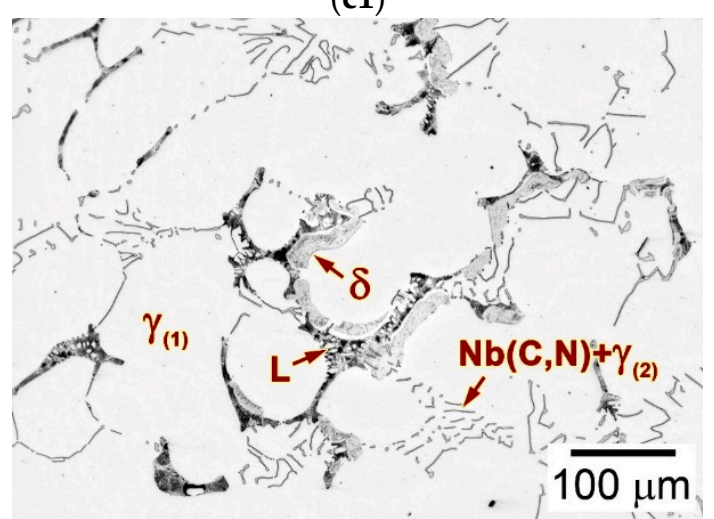

(d1)

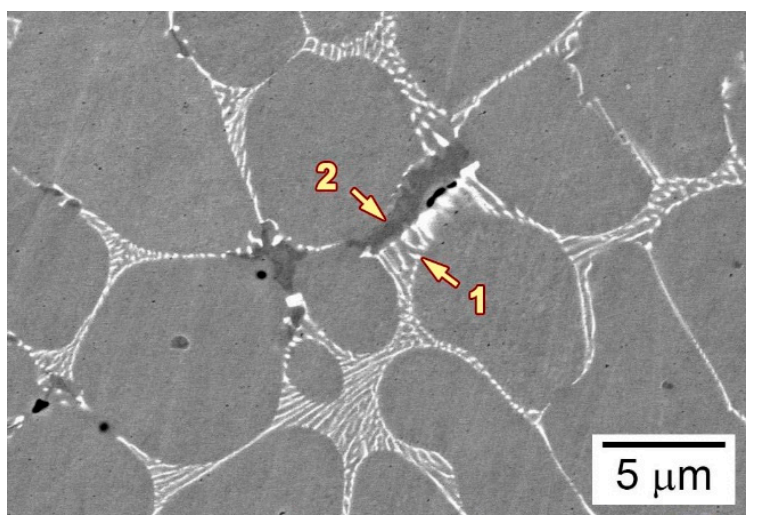

(a2)

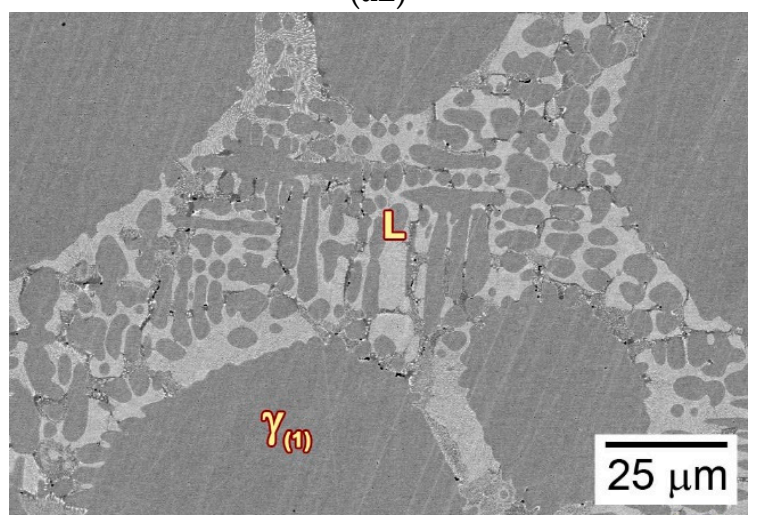

(b2)

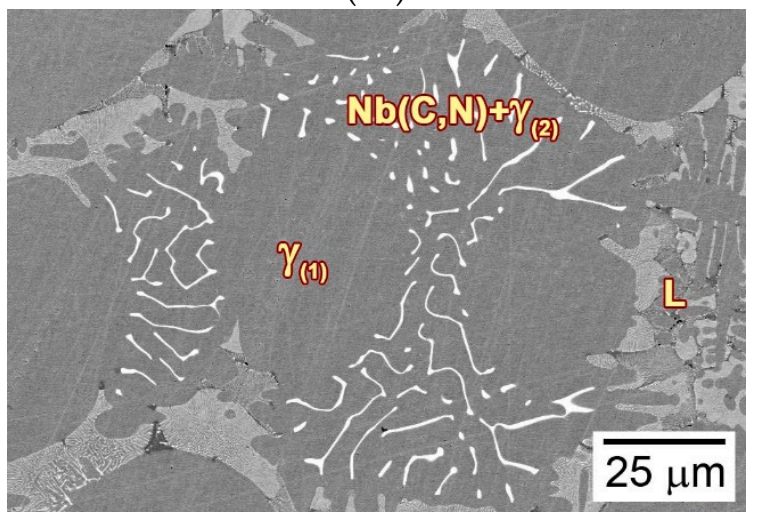

(c2)

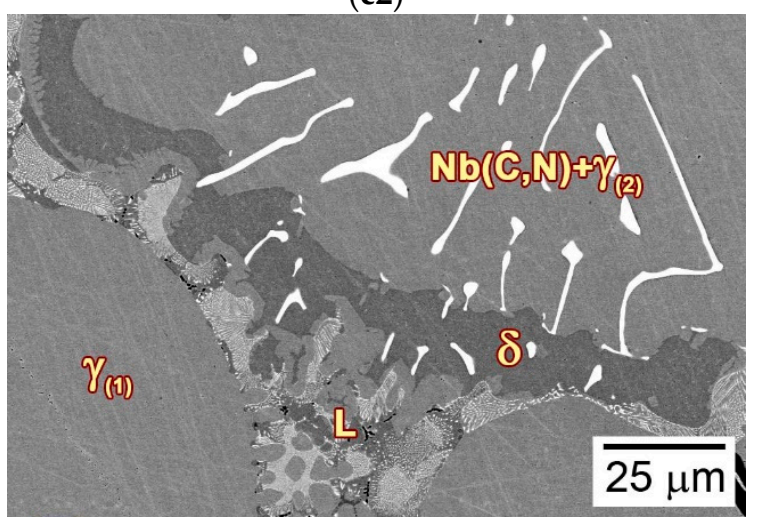

(d2)

Figure 8. Cont. 


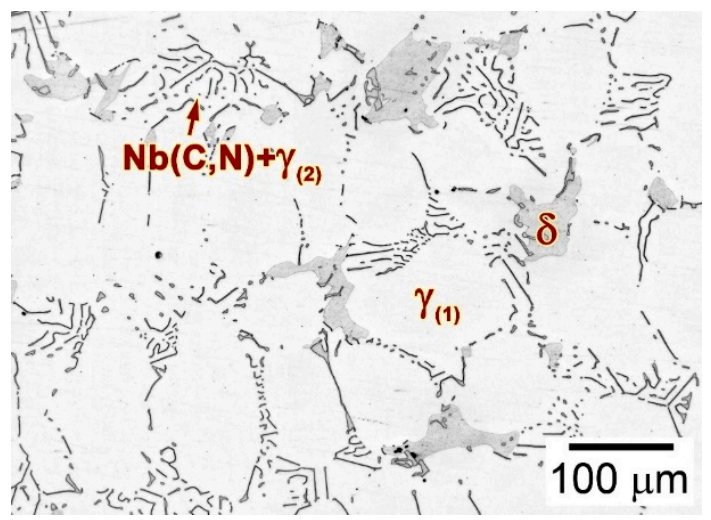

(e1)

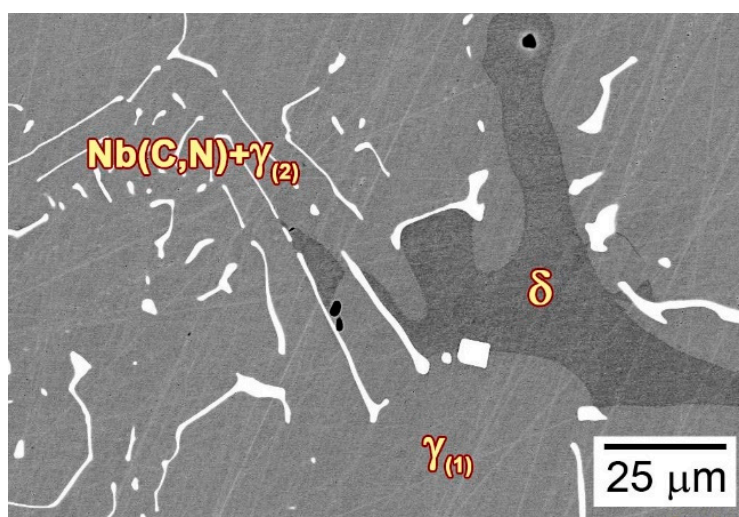

(e2)

Figure 8. Optical and enlarged SEM-BSE images showing the typical microstructure of each solidification stage marked by red circles in Figure $6 \mathrm{a}$ under the withdraw rate of $20 \mu \mathrm{m} / \mathrm{s}$ : $(\mathbf{a} 1, \mathbf{a} 2)$ stage I; (b1,b2) stage II; (c1,c2) stage III; (d1,d2) stage IV; (e1,e2) stage V.

Figure 9 shows the typical microstructure of each solidification stage marked by red circles in Figure $6 \mathrm{~b}$ at the withdraw rate of $50 \mu \mathrm{m} / \mathrm{s}$. Stage I revealed the fine dendritic microstructure (Figure 9a1), with the similar quenched SDAS as being $20 \mu \mathrm{m} / \mathrm{s}$, as well as the fine $\mathrm{Nb}(\mathrm{C}, \mathrm{N})$ carbonitride (marked by " 1 ") and $\delta$-ferrite (marked by "2") in the interdendritic regions (Figure 9a2). As solidification began in stage II, $\gamma$-austenite solidified primarily (Figure 9b1), and formed a much finer SDAS than that at $20 \mu \mathrm{m} / \mathrm{s}$. The liquid phase flowed smoothly along the interdendritic regions, though the fraction of solid phase increased rapidly in this stage (Figure 9b1,b2). The eutectic reaction (Equation (2)) regarding the formation of $\mathrm{Nb}(\mathrm{C}, \mathrm{N})$ carbonitride occurred subsequently in stage III by consuming the residual liquid phase (Figure 9c1). Comparing the lamellar $\mathrm{Nb}(\mathrm{C}, \mathrm{N})$ carbonitrides forming at 20 and $50 \mu \mathrm{m} / \mathrm{s}$, the interlamellar spacing was decreased significantly with an increase in the withdraw rate (Figures 8 and 9). The solidification ended in stage IV, where $\delta$-ferrite solidified at the expense of the last liquid phase in the interdendritic regions, and formed a vermicular morphology (Figure 9d1,d2). Therefore, the solidified microstructure of alloy $3 \mathrm{C} 2 \mathrm{~N}$ consisted of fine, "Chinese-script" $\mathrm{Nb}(\mathrm{C}, \mathrm{N})$ carbonitride, and the vermicular $\delta$-ferrite (Figure $9 \mathrm{e} 1, \mathrm{e} 2) \cdot(\mathrm{Cr}, \mathrm{Fe}){ }_{23} \mathrm{C}_{6}$ carbide was not observed in the mushy zone, whereas it precipitated in the following steady-state zone.

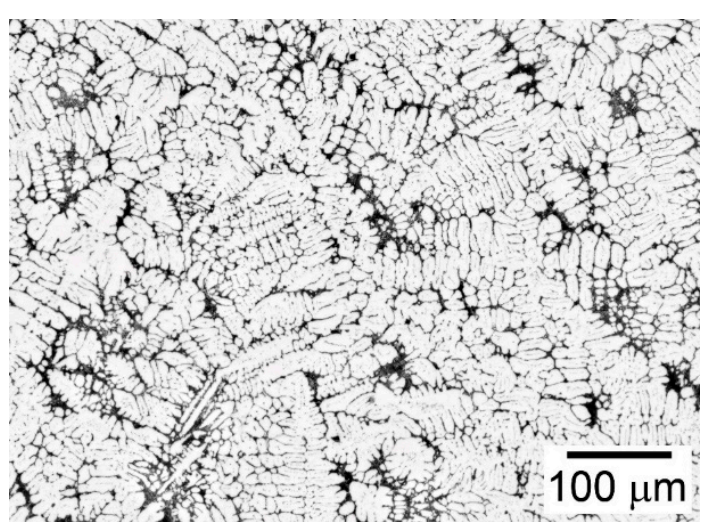

(a1)

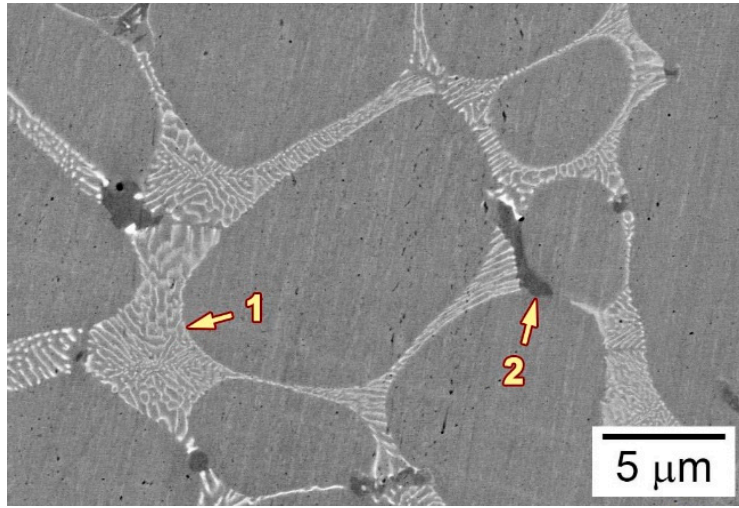

(a2)

Figure 9. Cont. 


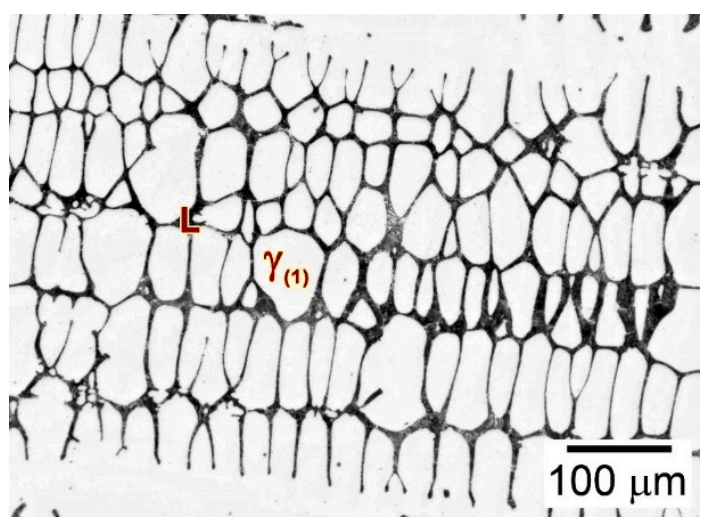

(b1)

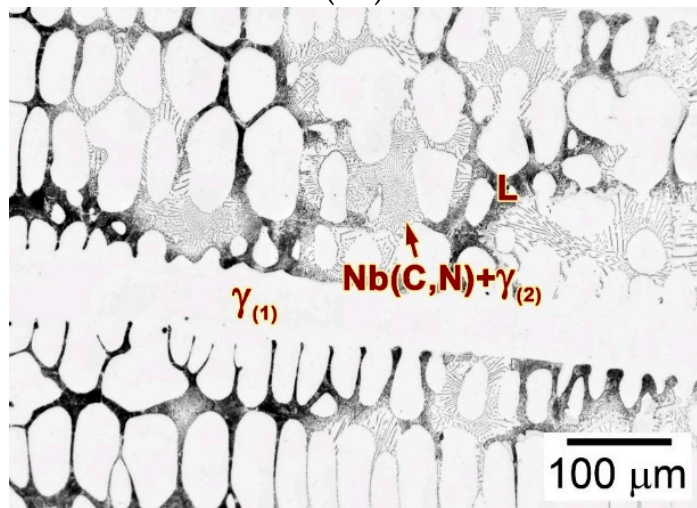

(c1)

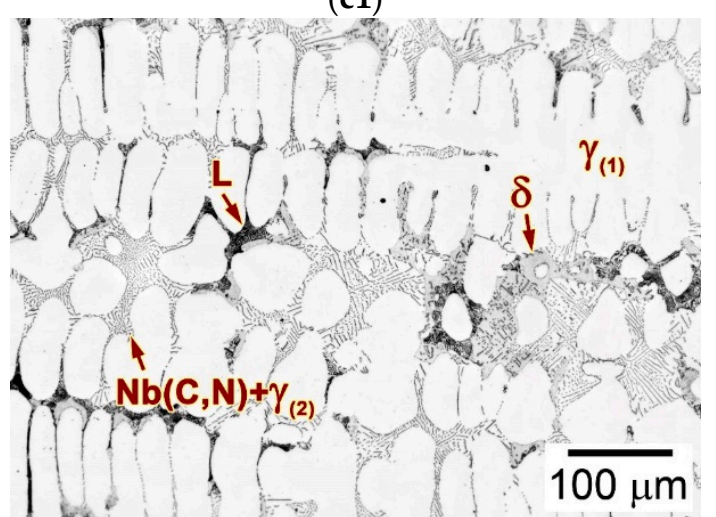

(d1)

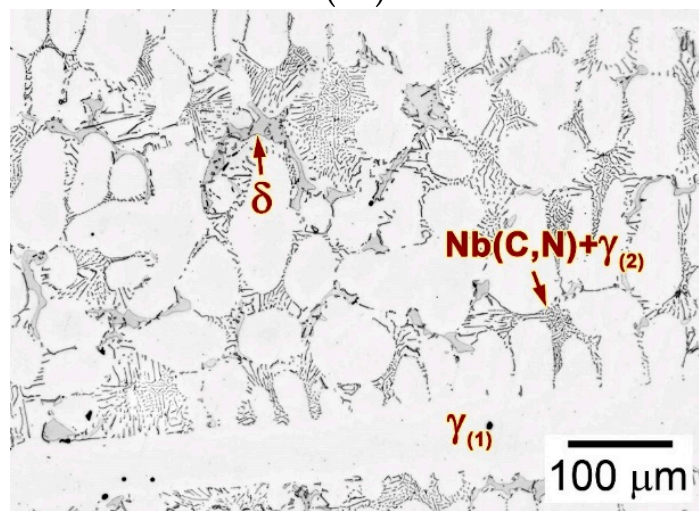

(e1)

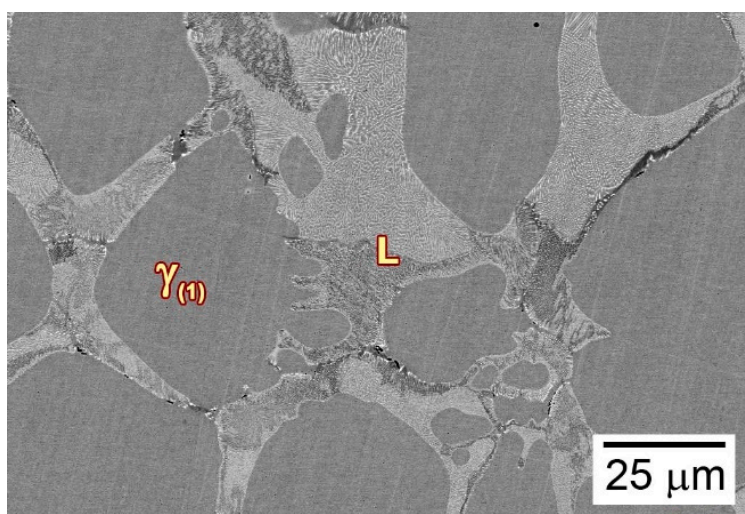

(b2)

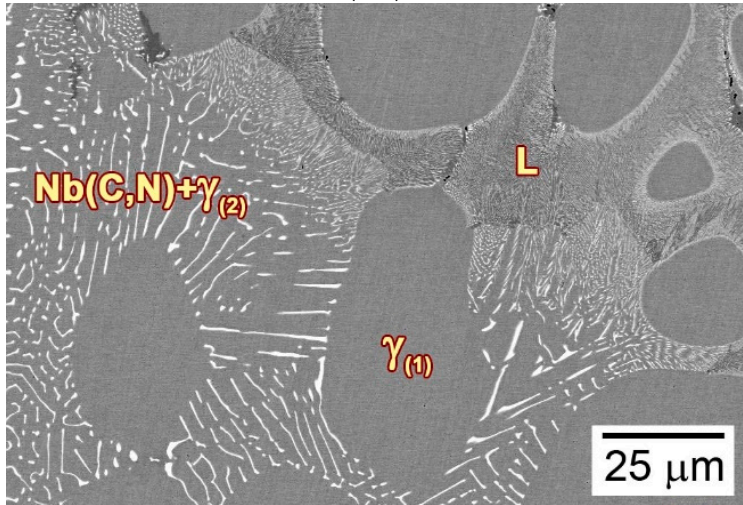

(c2)

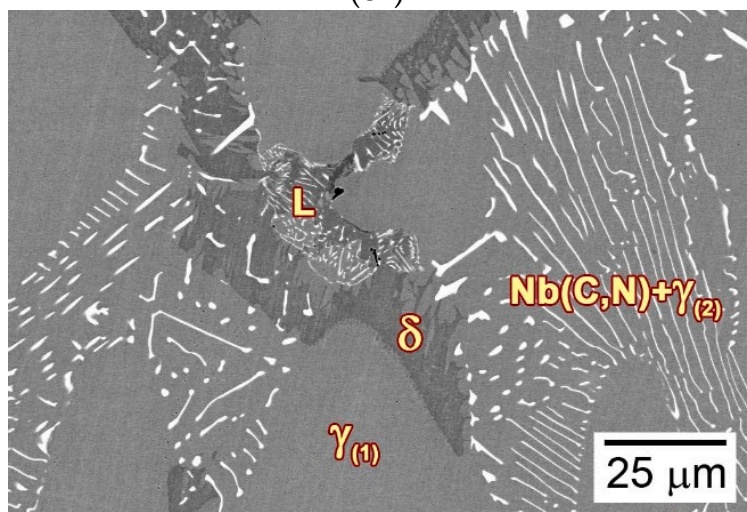

(d2)

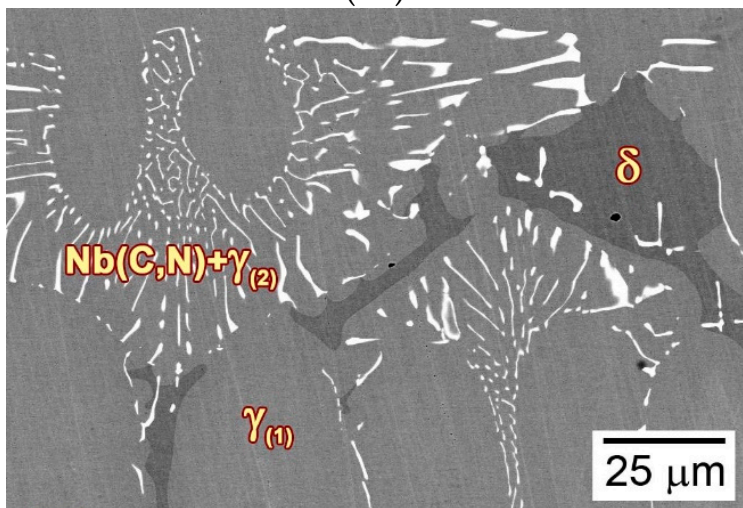

(e2)

Figure 9. Optical and enlarged SEM-BSE images showing the typical microstructure of each solidification stage marked by red circles in Figure $6 \mathrm{~b}$ under the withdraw rate of $50 \mu \mathrm{m} / \mathrm{s}$ : (a1,a2) stage I; (b1,b2) stage II; (c1,c2) stage III; (d1,d2) stage IV; (e1,e2) stage V. 


\subsubsection{Chemical Composition of the Liquid Phase}

Chemical composition of liquid phase was profoundly associated with the formation mechanism of different phases ( $\gamma$-austenite, $\mathrm{Nb}(\mathrm{C}, \mathrm{N})$ and $\delta$-ferrite) in as-cast alloy $3 \mathrm{C} 2 \mathrm{~N}$ during the LMC-DS process. Figure 10 shows the measured chemical composition of the liquid phase in each solidification stage marked by red circles in Figure $6 \mathrm{~b}$ at the withdraw rate of $50 \mu \mathrm{m} / \mathrm{s}$. It is interesting that the contents of $\mathrm{Nb}, \mathrm{C}$, and $\mathrm{N}$ increased in stage II and III, and then decreased in stage IV, whilst the $\mathrm{Cr}$ content increased continuously and significantly until the solidification ended in stage IV. A slight increase in the content of $\mathrm{Si}$ and $\mathrm{Mn}$ was also noted, rather than $\mathrm{Ni}$ and $\mathrm{Fe}$, which the content decreased.

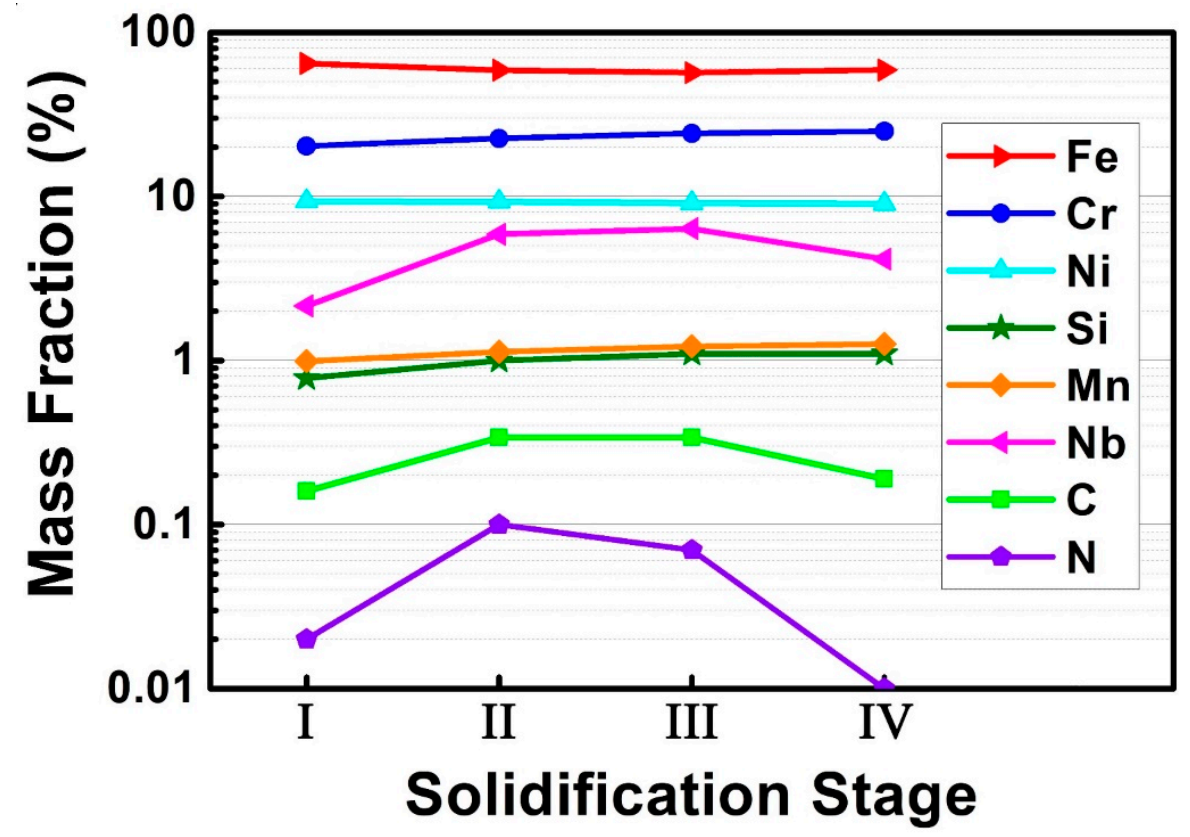

Figure 10. Chemical composition of the liquid phase in different solidification stages marked by red circles in Figure $6 \mathrm{~b}$ under the withdraw rate of $50 \mu \mathrm{m} / \mathrm{s}$, quantitatively measured by field emission electron probe microanalyzer (FE-EPMA).

\section{Discussion}

A series of $\mathrm{Nb}$-bearing cast austenitic heat-resistant steels were designed for ultra-high temperature applications in our previous study [7]. Their creep properties have significant microstructural dependence at $1000{ }^{\circ} \mathrm{C}$ and $50 \mathrm{MPa}$, particularly on the morphology of $\mathrm{Nb}(\mathrm{C}, \mathrm{N})$ carbonitride, as shown in Figure 11. Note that the creep properties of alloys with "Chinese-script" $\mathrm{Nb}(\mathrm{C}, \mathrm{N})$ carbonitride are much better than that with flake-blocky or facet-blocky $\mathrm{Nb}(\mathrm{C}, \mathrm{N})$ carbonitride. This is primarily attributed to the "Chinese-script" $\mathrm{Nb}(\mathrm{C}, \mathrm{N})$ carbonitride that prevents the sliding of grain boundaries at $1000{ }^{\circ} \mathrm{C}$, thus improving the interdendritic strength of these alloys. More interesting, the "Chinese-script" $\mathrm{Nb}(\mathrm{C}, \mathrm{N})$ carbonitride with finer interlamellar spacing can improve the creep resistance of this type of alloys much more effectively than the coarse carbonitride. It is thus important to elucidate the formation mechanism of $\mathrm{Nb}(\mathrm{C}, \mathrm{N})$ carbonitride and to grow this fine "Chinese-script" $\mathrm{Nb}(\mathrm{C}, \mathrm{N})$ carbonitride.

Indeed, the solidification behavior of this type of heat-resistant alloys is profoundly associated with both the chemical composition and the solidification processing. Our previous study reports that these alloys solidify in three modes, depending on the $\mathrm{C}$ and $\mathrm{N}$ additions: AEF mode (primary austenite + eutectic $\mathrm{Nb}(\mathrm{C}, \mathrm{N})+$ secondary ferrite), FAEF mode (primary ferrite + secondary austenite + eutectic $\mathrm{Nb}(\mathrm{C}, \mathrm{N})+$ secondary ferrite) and CAE mode (primary $\mathrm{Nb}(\mathrm{C}, \mathrm{N})$ carbonitride + primary austenite + eutectic $\mathrm{Nb}(\mathrm{C}, \mathrm{N})$ ) [23]. The microstructural characterization of the mushy zones in as-cast alloy $3 \mathrm{C} 2 \mathrm{~N}$ demonstrates that the different phases solidified in the order of primary $\gamma$-austenite, eutectic $\mathrm{Nb}(\mathrm{C}, \mathrm{N})$ 
carbonitride, and then secondary $\delta$-ferrite (Figures 8 and 9), regardless of the withdraw rate. Therefore, the solidification path of alloy $3 \mathrm{C} 2 \mathrm{~N}$ falls in the AEF mode, and can be described as:

$$
\begin{gathered}
\mathrm{L} \rightarrow \mathrm{L}+\gamma_{(1)} \rightarrow \mathrm{L}+\gamma_{(1)}+\left(\mathrm{Nb}(\mathrm{C}, \mathrm{N})+\gamma_{(2)}\right)_{\text {eutectic }} \rightarrow \mathrm{L}+\gamma_{(1)}+\left(\mathrm{Nb}(\mathrm{C}, \mathrm{N})+\gamma_{(2)}\right)_{\text {eutectic }}+\delta \rightarrow \\
\gamma_{(1)}+\left(\mathrm{Nb}(\mathrm{C}, \mathrm{N})+\gamma_{(2)}\right)_{\text {eutectic }}+\delta
\end{gathered}
$$

This solidification path agrees well with the solidification sequence that is calculated by JMatPro software (Equation (1)), suggesting that it is credible to predict the solidification behavior of these alloys through thermodynamic methods.

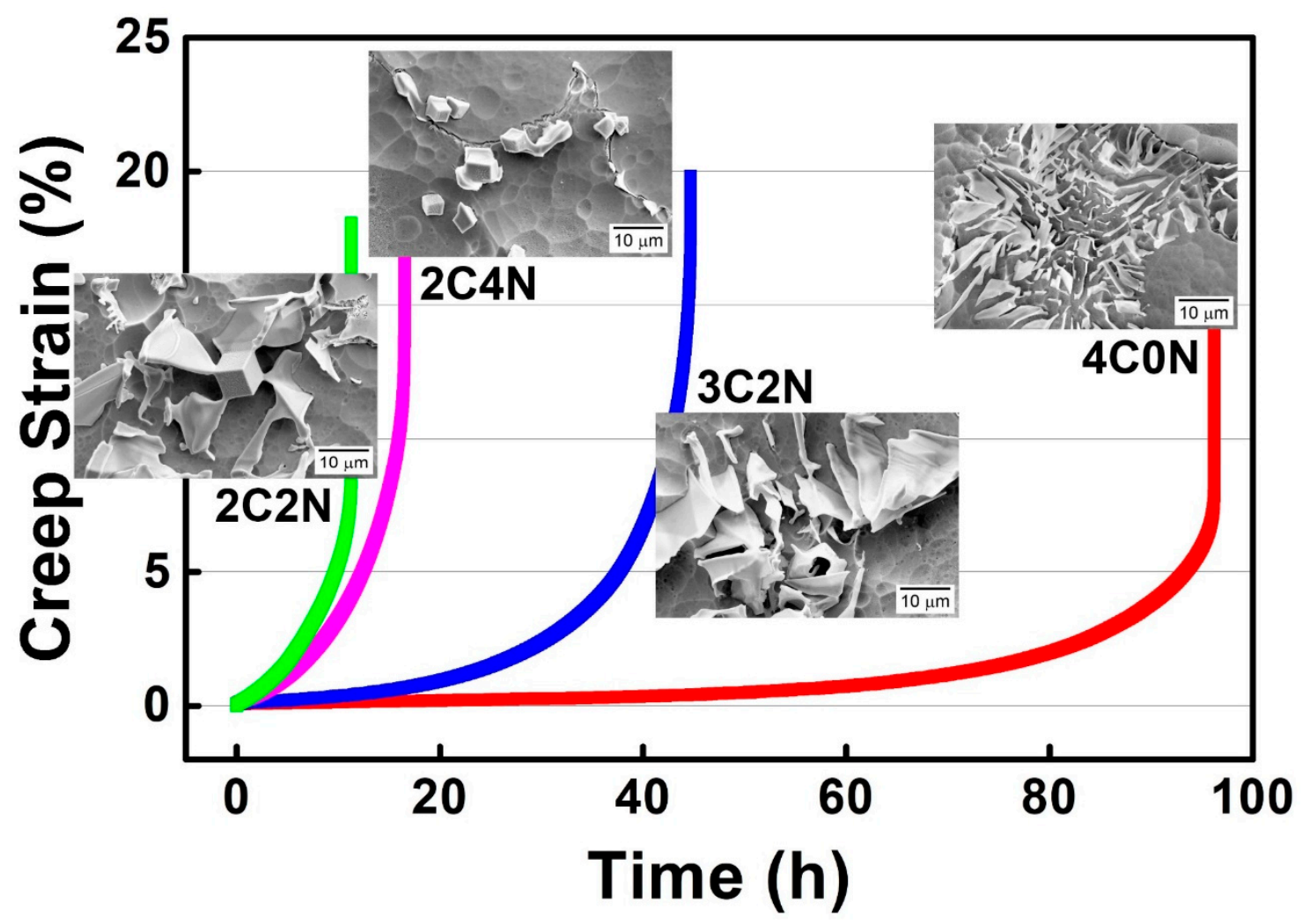

Figure 11. Schematic image showing the relationship between creep property and the microstructure of novel cast austenitic heat-resistant steels at $1000^{\circ} \mathrm{C}$ and $50 \mathrm{MPa}$.

Although the solidification path was not changed by increasing the withdraw rate from 20 to $50 \mu \mathrm{m} / \mathrm{s}$, the eutectic reaction (Equation (2)) range and the PDAS and SDAS, as well as the interlamellar spacing of the "Chinese-script" $\mathrm{Nb}(\mathrm{C}, \mathrm{N})$ carbonitride were influenced evidently (Figures 6, 8 and 9). It is generally recognized that the temperature gradient $\left(G_{L}\right)$ at the $L / S$ interface and the overall withdraw rate (i.e., growth rate, $\mathrm{V}$ ) play a paramount role in determining the morphology and size of different phases during the LMC-DS process [27]. Since the temperature gradient was kept constant, the withdraw rate is expected to dominate such microstructural alternation.

The eutectic reaction range is expanded, primarily due to the higher withdraw rate of $50 \mu \mathrm{m} / \mathrm{s}$ which induces a larger undercooling. Therefore, austenitic dendrite grows faster at temperatures below the liquidus temperature and a high fraction of solid phase (about $65 \%$ ) is reached in a shorter time (Figure 7). This contributes to a more rapid accumulation of solutes ( $\mathrm{Nb}, \mathrm{C}$, and $\mathrm{N}$ ) rejected from $\gamma$-austenite into liquid phase (Figure 10), and enables the elemental concentration to achieve the threshold of eutectic reaction at higher positions of the mushy zone. As a result, the "Chinese-script" $\mathrm{Nb}(\mathrm{C}, \mathrm{N})$ carbonitride is allowed to form at the distance of $2.6 \mathrm{~mm}$ away from the $\mathrm{L} / \mathrm{S}$ interface through the eutectic approach and the eutectic reaction range is widened accordingly (Figure 6b). It should also be noted that the two peaks on the faction curve withdrawn at $20 \mu \mathrm{m} / \mathrm{s}$ correspond to the formation 
of floating crystals in stage I, which will remelt at temperatures far beyond the eutectic temperature (Figures 6 and 7). Therefore, these high fractions cannot affect the accumulation of solutes, and thus, the eutectic reaction range.

The PDAS and SDAS are inversely proportional to the $G_{L} \times V$ product (cooling rate, $R$ ) [31]. Actually, plenty of efforts have been paid to investigate the relationship between the PDAS/SDAS and the withdraw rate/cooling rate [32-34]. Because the temperature gradient approximates the constant $\left(0.01^{\circ} \mathrm{C} / \mu \mathrm{m}\right)$, the relationship between the PDAS $\left(\lambda_{1}\right)$ and the withdraw rate can be described as:

$$
\lambda_{1}=\mathrm{A} \times \mathrm{G}_{\mathrm{L}}^{-\mathrm{m}} \times \mathrm{V}^{-\mathrm{n}}=\mathrm{B} \times \mathrm{V}^{-\mathrm{n}}
$$

where A, B, m, and $\mathrm{n}$ are coefficients [31]. Using the PDASs (298.2 and $152.4 \mu \mathrm{m})$ at the withdraw rate of 20 and $50 \mu \mathrm{m} / \mathrm{s}, \mathrm{B}$ and $\mathrm{n}$ are calculated to be 2656 and 0.73 , respectively. Therefore, Equation (4) can be modified as:

$$
\lambda_{1}=2656 \times \mathrm{V}^{-0.73}
$$

The values of $\mathrm{B}$ and $\mathrm{n}$ are comparable to that of a $\mathrm{Mg}-4 \mathrm{Al}-4 \mathrm{Ca}$ (AX44) alloy during directional solidification reported by Zheng et al. [33].

The relationship between the SDAS $\left(\lambda_{2}\right)$ and the withdraw rate/cooling rate is expressed as:

$$
\lambda_{2}=\mathrm{a} \times\left(\mathrm{G}_{\mathrm{L}} \times \mathrm{V}\right)^{-\mathrm{x}}=\mathrm{a} \times \mathrm{R}^{-\mathrm{x}}=\mathrm{b} \times \mathrm{V}^{-\mathrm{x}}
$$

where $a, b$, and $x$ are coefficients [31]. Using the SDASs $(88.8$ and $42.3 \mu \mathrm{m})$ at the withdraw rate of 20 and $50 \mu \mathrm{m} / \mathrm{s}, \mathrm{a}, \mathrm{b}$, and $\mathrm{x}$ can be calculated to be 24, 1005, and 0.83, respectively. Accordingly, Equation (6) can be modified as:

$$
\lambda_{2}=24 \times \mathrm{R}^{-0.81}=1005 \times \mathrm{V}^{-0.81}
$$

The value of a is comparable to that of conventional steels, whereas the value of $x$ appears to be a bit higher [34]. This might be attributed to there being plenty of alloying elements in alloy $3 \mathrm{C} 2 \mathrm{~N}$, particularly the large content of $\mathrm{Nb}, \mathrm{C}$, and $\mathrm{N}$, prohibiting the growth of austenitic dendrite.

The alternation in the interlamellar spacing of the "Chinese-script" $\mathrm{Nb}(\mathrm{C}, \mathrm{N})$ carbonitride can be attributed to the variations of the $G_{L} / V$ ratio. Previous studies have reported that the morphology of solidification growth front changes from planar to cellular, and then to dendritic features with decreasing the $G_{L} / V$ ratio [27,31]. Decreasing the withdraw rate from 50 to $20 \mu \mathrm{m} / \mathrm{s}$ increases the $G_{L} / V$ ratio, and thus inhibits the growth front to form dendrites. This will retard the formation of "Chinese-script" $\mathrm{Nb}(\mathrm{C}, \mathrm{N})$ carbonitride, since it prefers to solidify on dendritic interfaces (Figures 8 and 9). In addition, the relatively low withdraw rate increases the SDAS, and reduces the diffusion rate of solutes between the solid and liquid phases. As a result, the eutectic reaction (equation 2) becomes unstable, through which the $\mathrm{Nb}(\mathrm{C}, \mathrm{N})$ carbonitride retains the "Chinese-script" morphology, but significantly increases the interlamellar spacing. If the decline of the withdraw rate continues, the $\mathrm{Nb}(\mathrm{C}, \mathrm{N})$ carbonitride is expected to form faceted and blocky morphologies, without any "Chinese-script" characteristics, similar to that in Ni-based alloys [25]. In contrast, a high withdraw rate facilitates the formation of "Chinese-script" $\mathrm{Nb}(\mathrm{C}, \mathrm{N})$ carbonitride with small interlamellar spacing, as that in the quenched microstructure (Figures 8 and 9). It is thus suggested that the withdraw rate is increased for the purpose of fine "Chinese-script" $\mathrm{Nb}(\mathrm{C}, \mathrm{N})$ carbonitride during solidification.

However, increasing the withdraw rate or the cooling rate should take the macro-grain structure into consideration as well, because fine grains are detrimental to high temperature mechanical properties $[7,12,13]$. Grains generally decrease with the increase of the withdraw rate or cooling rate (Figure 5), due to the high nucleation rate and insufficient time for the diffusion of solutes [31]. It is thus required to set an upper limit for the withdraw rate or cooling rate of this type of heat-resistant alloys in future study. 
Besides the $\mathrm{Nb}(\mathrm{C}, \mathrm{N})$ carbonitride and the macro-grain structure, the $(\mathrm{Cr}, \mathrm{Fe}){ }_{23} \mathrm{C}_{6}$ carbide affects the ultra-high temperature creep property of these alloys as well. Our previous study recognized that the $(\mathrm{Cr}, \mathrm{Fe})_{23} \mathrm{C}_{6}$ carbide coarsens at $1000{ }^{\circ} \mathrm{C}$, and thus accelerates the nucleation and propagation of creep cracks [12]. Therefore, the quantity of $(\mathrm{Cr}, \mathrm{Fe})_{23} \mathrm{C}_{6}$ carbide should be strictly limited to reduce the adverse effects. The LMC-DS processing confirms that the precipitation of $(\mathrm{Cr}, \mathrm{Fe})_{23} \mathrm{C}_{6}$ carbide is retarded to the steady-state zone of alloy $3 \mathrm{C} 2 \mathrm{~N}$ [10], indicating that the contents of $\mathrm{C}$ and $\mathrm{Nb}$ are proper for this alloy design. Therefore, it is of great potential to improve the high temperature mechanical property of alloy $3 \mathrm{C} 2 \mathrm{~N}$ through increasing the withdraw rate or cooling rate during casting.

\section{Conclusions}

Liquid metal cooling directional solidification of a novel cast austenitic heat-resistant steel was carried out under the withdraw rates of 20 and $50 \mu \mathrm{m} / \mathrm{s}$. The formation mechanism of $\mathrm{Nb}(\mathrm{C}, \mathrm{N})$ carbonitride is elucidated, which is helpful for guidance producing fine "Chinese-script" $\mathrm{Nb}(\mathrm{C}, \mathrm{N})$ carbonitride, and thus improving mechanical properties at ultra-high temperatures. Conclusions are drawn as follows.

1. The solidification path of alloy $3 \mathrm{C} 2 \mathrm{~N}$ can be described as $\mathrm{L} \rightarrow \mathrm{L}+\gamma_{(1)} \rightarrow \mathrm{L}+\gamma_{(1)}+(\mathrm{Nb}(\mathrm{C}, \mathrm{N})$ $\left.+\gamma_{(2)}\right)_{\text {eutectic }} \rightarrow \mathrm{L}+\gamma_{(1)}+\left(\mathrm{Nb}(\mathrm{C}, \mathrm{N})+\gamma_{(2)}\right)_{\text {eutectic }}+\delta \rightarrow \gamma_{(1)}+\left(\mathrm{Nb}(\mathrm{C}, \mathrm{N})+\gamma_{(2)}\right)_{\text {eutectic }}+\delta$, which agrees with the solidification sequence as calculated by thermodynamic methods.

2. The PDAS $\left(\lambda_{1}\right)$ and SDAS $\left(\lambda_{2}\right)$ are inversely proportional to the withdraw rate $(\mathrm{V})$ and cooling rate (R), and the relationship can be described as $\lambda_{1}=2656 \times \mathrm{V}^{-0.73}$ and $\lambda_{2}=24 \times \mathrm{R}^{-0.81}=1005$ $\times \mathrm{V}^{-0.81}$, respectively.

3. The eutectic reaction range increases with an increase in the withdraw rate, which is primarily attributed to the larger undercooling that induces a rapid increase of the solid phase fraction and an accumulation of solutes in liquid phase.

4. Increasing the withdraw rate facilitates the formation of "Chinese-script" $\mathrm{Nb}(\mathrm{C}, \mathrm{N})$ carbonitride with small interlamellar spacing, whereas the rate should also be limited for the consideration of preventing fine grains.

Author Contributions: Y.Z. conceived and designed this research. Y.Z. performed the experiments and simulations. Y.Z. analyzed the experimental results and wrote this manuscript. J.Y. contributed the consultation and paper preparation. J.Y. contributed correction of English and proofreading.

Funding: This research was supported by the National Natural Science Foundation of China (No. 51801118), the Project funded by China Postdoctoral Science Foundation (No. 2017M621430), and the University Research Program (URP) between Ford Motor Company, USA and the University of Science and Technology Beijing.

Acknowledgments: The authors are grateful to Q. Feng and M. Li for suggestions on designing this research; L.W. Zhang and X.F. Zhang are also acknowledged, specially for the full support on directional solidification experiments and materials characterizations, respectively.

Conflicts of Interest: The authors declare no conflict of interest.

\section{References}

1. Fukai, N.; Imamura, T.; Ito, K.; Kuribayashi, Y. Challenges to expand eco-products with high functional materials and components. Hitachi Rev. 2008, 57, 248-252.

2. Karnik, A.Y.; Shelby, M.H. Effect of exhaust gas temperature limits on the peak power performance of a turbocharged gasoline engine. J. Eng. Gas Turb. Power 2010, 132, 112801-112807. [CrossRef]

3. Itoh, K.; Hayashi, K.; Souda, T. Development of HERCUNITE ${ }^{\circledR}-S$ NSHR ${ }^{\circledR}$-A5N for high performance gasoline engines. Hitachi Met. Tech. Rev. 2006, 22, 51-56.

4. Ike, M.; Akiyama, K.; Ohtsuka, K.; Itoh, K. Development of heat-resistant cast steel for exhaust manifolds. Int. J. Mater. Prod. Technol. 1991, 6, 243-256.

5. Shingledecker, J.P.; Maziasz, P.J.; Evans, N.D.; Pollard, M.J. Creep behavior of a new cast austenitic alloy. Int. J. Pres. Ves. Pip. 2007, 84, 21-28. [CrossRef] 
6. Maziasz, P.J. Development of creep-resistant and oxidation-resistant austenitic stainless steels for high temperature applications. JOM 2018, 70, 66-75. [CrossRef]

7. Zhang, Y.H.; Li, M.; Godlewski, L.A.; Zindel, J.W.; Feng, Q. Effective design of new austenitic cast steels for ultra-high temperature automotive exhaust components through combined CALPHAD and experimental approaches. Mater. Sci. Eng. A 2017, 683, 195-206. [CrossRef]

8. Zhang, Y.H.; Feng, Q. Effects of $\mathrm{W}$ on creep behaviors of novel Nb-bearing austenitic heat-resistant cast steels at $1000^{\circ} \mathrm{C}$. Acta Metall. Sin. 2017, 53, 1025-1037. [CrossRef]

9. Zhang, Y.H.; Li, M.; Godlewski, L.A.; Zindel, J.W.; Feng, Q. Effects of N on creep properties of austenitic heat-resistant cast steels developed for exhaust component applications at $1000{ }^{\circ} \mathrm{C}$. Acta Metall. Sin. 2016, 52, 661-671.

10. Zhang, Y.H.; Yang, J. Effect of N/C ratio on precipitation behavior of $(\mathrm{Cr}, \mathrm{Fe}){ }_{23} \mathrm{C}_{6}$ carbide in novel cast austenitic heat-resistant steels during directional solidification. Metals 2018, 8, 678. [CrossRef]

11. Zhao, H.L.; Engler-Pinto, C.C.; Zindel, J.; Godlewski, L.; Zhang, Y.H.; Feng, Q.; Li, M. The Effect of metal-carbide morphology on the thermomechanical fatigue (TMF) behavior of cast austenitic alloys for exhaust manifolds. Procedia Eng. 2015, 133, 669-680. [CrossRef]

12. Zhang, Y.H.; Li, M.; Godlewski, L.A.; Zindel, J.W.; Feng, Q. Effects of W on creep behaviors of novel $\mathrm{Nb}$-bearing high nitrogen austenitic heat-resistant cast steels at $1000{ }^{\circ} \mathrm{C}$. Mater. Charact. 2018, 139, $19-29$. [CrossRef]

13. Zhang, Y.H.; Li, M.; Godlewski, L.A.; Zindel, J.W.; Feng, Q. Creep behavior at $1273 \mathrm{~K}\left(1000{ }^{\circ} \mathrm{C}\right)$ in Nb-bearing austenitic heat-resistant cast steels developed for exhaust component applications. Metall. Mater. Trans. A 2016, 47, 3289-3294. [CrossRef]

14. Zhao, H.L.; Engler-Pinto, C.C.; Tong, J.Y.; Godlewski, L.A.; Zindel, J.W.; Li, L.F.; Li, M.; Feng, Q. Mechanical response and dislocation substructure of a cast austenitic steel under low cycle fatigue at elevated temperatures. Mater. Sci. Eng. A 2017, 703, 422-429. [CrossRef]

15. Tin, S.; Pollock, T.M.; Murphy, W. Stabilization of thermosolutal convective instabilities in Ni-based single-crystal superalloys: Carbon additions and freckle formation. Metall. Mater. Trans. A 2001, 32, 1743-1753. [CrossRef]

16. Li, X.W.; Wang, L.; Dong, J.S.; Lou, L.H. Effect of solidification condition and carbon content on the morphology of MC carbide in directionally solidified nickel-base superalloys. J. Mater. Sci. Technol. 2014, 30, 1296-1300. [CrossRef]

17. Zhang, H.W.; Qin, X.Z.; Li, X.W.; Zhou, L.Z. Effect of minor additions on the microstructures and stress rupture properties of a directionally solidified Ni-based superalloy. Mater. Sci. Eng. A 2018, 711, 303-312. [CrossRef]

18. Antonov, S.; Chen, W.; Huo, J.J.; Feng, Q.; Isheim, D.; Seidman, D.N.; Sun, E.; Tin, S. MC carbide characterization in high refractory content powder-processed Ni-based superalloys. Metall. Mater. Trans. A 2018, 49, 2340-2351. [CrossRef]

19. Chen, Q.Z.; Jones, C.N.; Knowles, D.M. Effect of alloying chemistry on MC carbide morphology in modified RR2072 and RR2086 SX superalloys. Scr. Mater. 2002, 47, 669-675. [CrossRef]

20. Min, K.S.; Nam, S.W. Correlation between characteristics of grain boundary carbides and creep-fatigue properties in AISI 321 stainless steel. J. Nucl. Mater. 2003, 322, 91-97. [CrossRef]

21. De Almeida, L.H.; Ribeiro, A.F.; Le May, I. Microstructural characterization of modified $25 \mathrm{Cr}-35 \mathrm{Ni}$ centrifugally cast steel furnace tubes. Mater. Charact. 2002, 49, 219-229. [CrossRef]

22. Piekarski, B. Effect of $\mathrm{Nb}$ and Ti additions on microstructure, and identification of precipitates in stabilized Ni-Cr cast austenitic steels. Mater. Charact. 2001, 47, 181-186. [CrossRef]

23. Zhang, Y.H.; Li, M.; Godlewski, L.A.; Zindel, J.W.; Feng, Q. Effects of N/C ratio on solidification behaviors of novel $\mathrm{Nb}$-bearing austenitic heat-resistant cast steels for exhaust components of gasoline engines. Metall. Mater. Trans. A 2017, 48, 1151-1162. [CrossRef]

24. Reed, R. Nitrogen in austenitic stainless steels. JOM 1989, 41, 16-21. [CrossRef]

25. Bhambri, A.K.; Kattamis, T.Z.; Morral, J.E. Cast microstructure of Inconel 713C and its dependence on solidification variables. Metall. Trans. B 1975, 6, 523-537. [CrossRef]

26. Liu, L.; Sommer, F.; Fu, H.Z. Effect of solidification conditions on MC carbides in a nickel-base superalloy IN 738 LC. Scr. Metall. 1994, 30, 587-591. [CrossRef] 
27. Buchanan, K.G.; Kral, M.V. Crystallography and morphology of niobium carbide in as-cast HP-niobium reformer tubes. Metall. Mater. Trans. A 2012, 43, 1760-1769. [CrossRef]

28. Buchanan, K.G.; Kral, M.V.; Bishop, C. Crystallography and morphology of MC carbides in niobium-titanium modified as-cast HP alloys. Metall. Mater. Trans. A 2014, 45, 3373-3385. [CrossRef]

29. Miller, J.D.; Pollock, T.M. Stability of dendrite growth during directional solidification in the presence of a non-axial thermal field. Acta Mater. 2014, 78, 23-36. [CrossRef]

30. Ding, X.F.; Lin, J.P.; Zhang, L.Q.; Wang, H.L.; Hao, G.J.; Chen, G.L. Microstructure development during directional solidification of Ti-45Al-8Nb alloy. J. Alloys Compd. 2010, 506, 115-119. [CrossRef]

31. Yu, Y.N.; Yang, P.; Qiang, W.J.; Chen, L. Foundations of Materials Science; High Education Press: Beijing, China, 2006; pp. 659-707.

32. Hunt, J.D.; Lu, S.Z. Numerical modeling of cellular/dendritic array growth: Spacing and structure predictions. Metall. Mater. Trans. A 1996, 27, 611-623. [CrossRef]

33. Zheng, X.; Luo, A.; Zhang, C.; Dong, J.; Waldo, R. Directional solidification and microsegregation in a magnesium-aluminum-calcium alloy. Metall. Mater. Trans. A 2012, 43, 3239-3248. [CrossRef]

34. Wang, Y.N.; Yang, J.; Xin, X.L.; Wang, R.Z.; Xu, L.Y. The effect of cooling conditions on the evolution of non-metallic inclusions in high manganese TWIP steels. Metall. Mater. Trans. B 2016, 47, 1378-1389. [CrossRef]

(C) 2018 by the authors. Licensee MDPI, Basel, Switzerland. This article is an open access article distributed under the terms and conditions of the Creative Commons Attribution (CC BY) license (http:/ / creativecommons.org/licenses/by/4.0/). 